\title{
Ayurveda approaches towards the management of sport injury w.s.r. to sport
}

\section{medicine}

Available online at www.ijistweb.com

REVIEW ARTICLE

Shekokar Anantkumar*, Borkar Kanchan

Dept. of Shalya Tantra, S.V.N.H.T'S Ayurved Mahavidyalaya, Rahuri Factory, India.

*Corresponding Author's E-mail: dranantkumarshekokar@gmail.com

\begin{abstract}
Ayurveda the ancient system of Indian medical science offers various principles and concept to remain healthy and live long life. Sports medicine is of the modality of Ayurveda science which deals with treatment and prevention of sport injury. The sports medicine is a novel concept of Ayurveda emerging from last few decades. Ayurveda offers various treatment modalities for sport injury such as; Marma therapy, oil massage, Yoga, Raktamokashana, Agnikarma, physiotherapy and herbal medication. The present article explores scope and utility of sport medicine as per Ayurveda.
\end{abstract}

Keywords: Agnikarma, sports medicine, sport injury, Marma, Raktamokshana.

\section{Introduction}

Ayurveda the traditional science of healing not only emphasized curative approaches but also offers preventive aspects. Sports medicine is one of the emerging concepts of Ayurveda which deals with maintenance of good physical and mental status of sport persons. Sports persons are susceptible towards the some common physical injuries such as; muscle cramp, shin splints, anterior cruciate ligament, ankle sprain, shock and fracture. Sports medicine along with Raktamokashana, Agnikarma and physiotherapy IMarma play vital role for the management of such conditions (1-4). The modern concept of sports medicine enables to covers specific area like; cardiology, orthopedic surgery, pulmonology, psychiatry, biomechanics and traumatology. The sport medicine of modern era offers desired therapeutic response in above mentioned specific area and treatment modality towards sport injury differs depending upon type of injury. Therefore as per Ayurveda variety of sport medicines are required for different types of sport injury along with Marma lyogic exercises (3-7).

According to Acharya Sushruta in the context of Agnikarma indication mentioned that when ligaments, joints and bones (deeper Structure) are affected by Vata and Kapha, such pathogenesis should be treated as Agnikarma therapy repeatedly without any doubt while when pathogenesis involved to Tvak, Mansa, Sira (superficial structure) then treated with Raktmokashana (2-6).

\section{Specific Role of Ayurveda in Sports Medicine:}

The traditional text of Ayurveda does not quoted directly regarding sport medicine but inherently proposed various aspects which may be correlated with sport medicine or sport injury. Ayurveda described concept of Dincharya which should be strictly followed by a sport person similarly concept of Rasayana medicine imparts beneficial effects in the physical personality of a sport person. As per Ayurveda there are seven Dhatu which contributes towards the structural and functional buildup of body, in sport medicine Mansa and Asthi Dhatu play vital role similarly Upadhatu such as; Snayu and Kandra also involve in sport injury. Prominent joints such as; Gulfa, Janu, Aratni, Jatru and Sthuladanta are vulnerable to sport injury. Ayurveda prescribed various Marma therapies along with natural medicine to empower strength of these Dhatus and Updhatus.

Acharya Sushuruta mentioned reference of Physiotherapy in the context of post fracture treatment rehabilitation with soil material ,Salt crystal and lastly Stony crystal useful one by one for affected fracture site of patients to 
restore normal function. Therefore we can say that Ayurveda directly or indirectly contributed greatly in the management of sport injury (3-7).

\section{Common Sport Injury/Sock/Trauma as per} Ayurveda:

Asthibhagna

Asthitoda

Dwijaprapatana

Sadana

Srama

Bhagna

Mamsagatvata

Sandhimukta

Snayugatvata

Ayurveda Treatment of Sport Injury
The common objectives of treating sport injury involve rehabilitation of injuries, active mobilization, passive mobilization, strengthening, boost up tissue healing process, manage pain and fixing of dislocated part. These objectives/goals may be achieved by using various Ayurveda formulations along with physiotherapy. Drugs belongs from Brimhaneeyadasaimani category boost muscle, Jeevaneeya Dasaimani acts as vitiliser and Balakara Dasaimani promotes strength hence these category of drugs also improves performance level of sport person. Similarly Draksha, Barbara, Priyala, Parooshaka, Iksu, Yava, Shastika, Dadima, Jeevaka, Phalgu, Rishabhaka, Meda, Mahameda, Kakoli, Ksheerakakoli, Jeevanti, Mashaparni and Mudgaparna are acts as performance enhancing agents thus may be used as sport medicine (4-8).

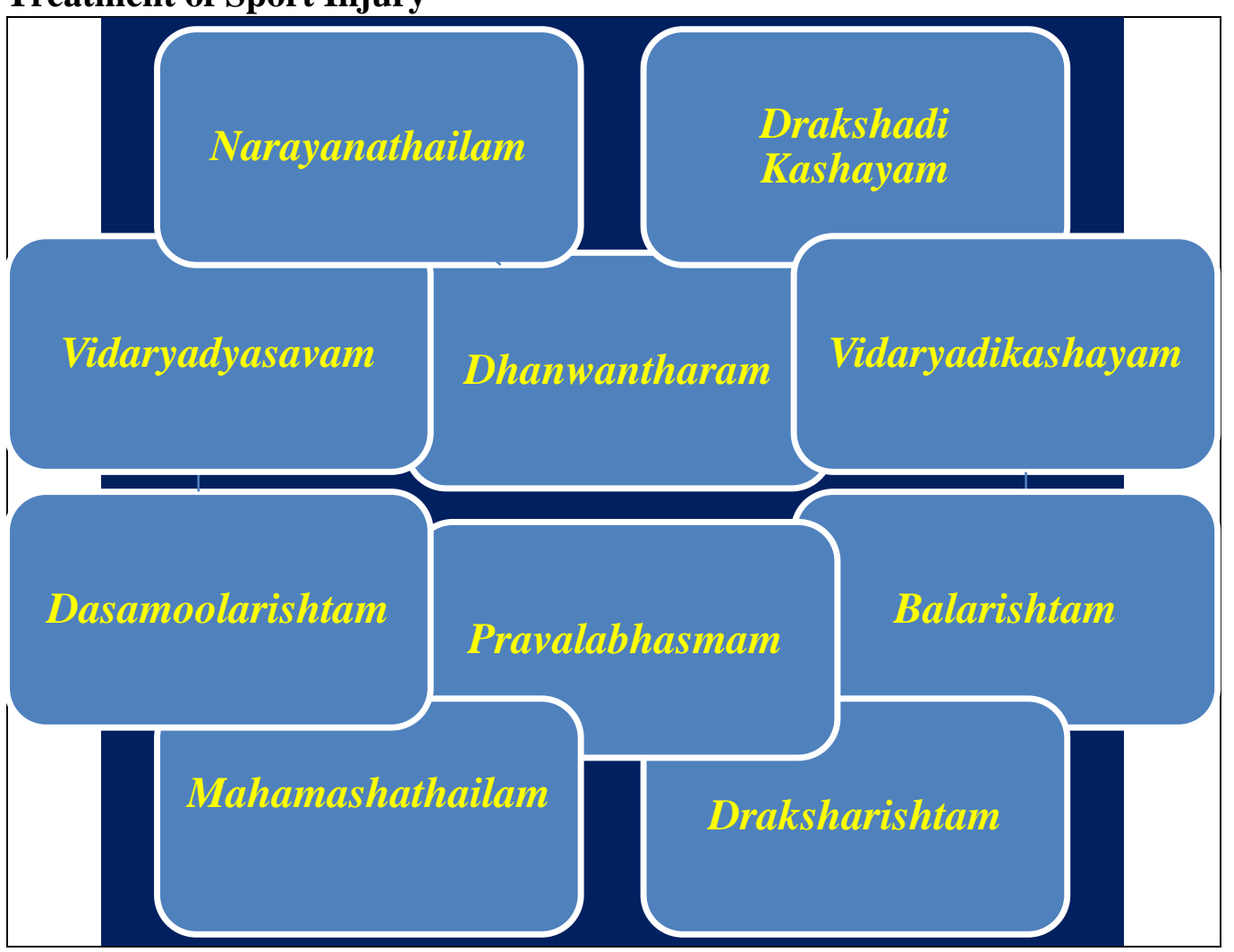

Figure 1: Some Ayurveda formulation recommended for sport injury

The specific Ayurveda treatment modalities and formulations exerted selective effect in sport injury as follows:

\section{* Lepana / Aalepa / Upanaha}

Manage pain

Promote tissue healing process

\section{* Raktamokashana}

Instant pain relief.

Restore Normal function.

\section{Agnikarma}

Instant relief in pain.

Improvement in restricted movements at the affected site.

Kati vasti 
Effective in back pain and in muscular pain.

\section{Bandhana}

Bandage with medicaments relief inflammation and pain.

\section{Snehan and swedan}

Table 1: Ayurveda therapy recommended as per various stages of sport injury

\begin{tabular}{|c|c|c|c|c|}
\hline S. No. & Stages & Internal medicine & External medicine & Yoga \\
\hline 1 & Initial phase & $\begin{array}{c}\text { Musthadi Marma } \\
\text { Kashayam }\end{array}$ & Ostalgin Oil & $\begin{array}{c}\text { Sasankasanam, } \\
\text { Bharadwajasanam, } \\
\text { Nikunchasanam and } \\
\text { Ardhamalsyenthrasanam. }\end{array}$ \\
\hline 2 & $\begin{array}{c}\text { Rehabilitation } \\
\text { pahse }\end{array}$ & $\begin{array}{c}\text { Dhanwantharam } \\
\text { Kashyam }\end{array}$ & $\begin{array}{l}\text { Dhanwantharam } \\
\text { Thailam And } \\
\text { Gandha Tailam }\end{array}$ & $\begin{array}{l}\text { Marjarasanam, } \\
\text { Vyagrasanam, } \\
\text { Noukasanam, } \\
\text { Shalabhasanam. }\end{array}$ \\
\hline 3 & $\begin{array}{c}\text { Conditioning } \\
\text { Phase }\end{array}$ & $\begin{array}{c}\text { Gulguluthikthakam } \\
\text { Gritham }\end{array}$ & $\begin{array}{c}\text { Shashtika } \\
\text { Thailam, } \\
\text { Mahamasha } \\
\text { Tailam, Pichu } \\
\text { With Ostalgin } \\
\text { Agnikarma } \\
\text { Raktmokashana }\end{array}$ & $\begin{array}{l}\text { Sasankasanam, } \\
\text { Vyagrasanam, } \\
\text { Noukasanam. }\end{array}$ \\
\hline
\end{tabular}

Traditional Medicines and Formulation as Sport Medicine:

The traditional medicines like Vranaropana Tailam, Satahvadi Tailam, Murivenna, Marma Tailam, Bala Tailam, Pinda Tailam, Dhanwantara Tailam, Maharajaprasarani Tailam, Mahamasha Tailam, Narayana Tailam and Ksirabala Tailam etc. may be used for the sports injuries. These drugs offer analgesic, antiinflammatory, relaxant and calming effects. Formulation such as; Bala Tailam, Maharajaprasarani Tailam, Dhanwantaram Tailam, Ksirabala Tailam and Mahamasha Tailam etc. offer local relief. Dhanwantaram Tailam is topical remedy recommended for chronic low back pain, spondylosis, fibromyalgia and muscular fatigue etc. Mahanarayana Tailam, Dhanwantaram Tailam and Chinchodi Tailam offer anti-inflammatory and analgesic activity. These drugs also recommended for joint pains, sprains and musculoskeletal injuries (6-10).

\section{Rasayana as Sports Medicine:}

Rasayana or rejuvenation therapy improves longevity, memory power, intelligence,
Snehan offers lubrication to joints; makes body flexible and act as painkiller.

Ayurveda also recommended some internal and external medicine along with yoga as per the various stages of sport injury which are as follows:

Raktmokashana 
muscles which are very susceptible for injury. The downward massage Mardana while squeezing the muscles is helpful in pacifying Mamsagata Vata. Another massage Samvahanam increases strength, alleviating vitiated Vata and Kapha doshas and remove fatigue. The massage with feet; Padaghata strengthen muscles and helps to combat against stress. The massage with medicated oils improves fitness, cures injuries, heals damaged muscles, stimulates blood circulation, releases stress, reduce pain and tension while Shalya Tantara treatment modalities like Agnikarma and Raktamokshana are beneficial to chronic musculoskeletal disorders (7-11).

\section{Conclusion}

Recent development in Ayurveda specially Shalya tantra science suggested various medicines for the management of good physical and mental status which is essential for a sport person, these internal medications also offers relief in injuries, edema, stiffness, pain and muscle strain. Ayurveda therapy provide relief in various sport injuries such as; heel pain, tendinitis, tenosynovitis, groin injury, supra spinatus tendinitis, ligament strain and minor fracture. Performance enhancement and physical fitness can be achieved with Ayurveda medicine which acts as sport medicine. Ayurveda approaches may be incorporated effectively in sports from beginning to the end. The various concept of Ayurveda suggested rules of healthy living which is very important for a sport person. The exercises and Yoga along with Agnikarma, Raktmokshana and also Ayurveda medicine cure injury; make strong physique and enhance performances. Rasayana therapy boosts stamina and classical method like Agnikarma and Raktmokashana can also be effectively used for the management of sport injury.

\section{Acknowledgement}

The authors are thankful to IJIST Journal for publishing their article.

\section{Conflicts of Interest}

The author declares that there are no conflicts of interest.
1. YG Joshi (2011) Charaksamhita, Maharshi Charak, Marathi commentary elaborated by caraka \& Drudhabala. Sutra - Stan (1st edn), chapter 1, Verse no.43, vaidyamitraprakashan, India, p.16.

2. JN Wilson (1982) Watson and Jones' textbook on Fractures and joint injuries, edited by J.N.Wilson. (6th edn), Volume 1, 9th chapter, Jama publication, India, pp.986.

3. Kapoor OP Kapoors (2000) Text book of medicine for general practitioners. Volume 1, SS publishers, India, pp. 240 .

4. Subhashranade (2006) Ashtangasangraha, Vagbhtakrytaindutika and its Marathi translation. Sutra stan (12th edn), chapter 1, Verse no.31, Anmol publishing house, India, p.5.

5. Ganesh Krushanagarde (2009) Sartha Vagbhat, VagbhtakrytaAshtangrudhaya and its Marathi translation. Sutra stan (12th edn), chapter 11, Verse no.18, Profesent publishing house, India, p.60.

6. Dr. Anantram Sharma, Sushruta Samhita Part-2, Chikitsa sthana Adhyay No.3 ,Bhagna Chikitsa ,sutra no 34/35, Chokhamba Surbharati Prakashan, Varanasi, $1^{\text {st }}$ Edition, 2004, P-196.

7. Anant Ram Sharma edited with 'susrutavimarsini' Hindi commentary (2010) Susrutasamhita, maharshisusruta. Chikitsa-stan, Chapter 4, verse no.8, Chukhambha prakashan, India, pp.205.

8. Bagde AB. Preventive Aspect of Vyayama (Physical Exercise). International Journal of Ayurveda and Alternative Medicine 2015; 3(1): 6-10.

9. Tonni SS, Wali AA. Dietary Considerations of Wound Healing in Ayurveda. JNFS 2013; 3(5): 227230.

10. Vriddha Vagbhat, Ashtang-Samgraha with Shashilekha commentary by Indu, edited by Dr. Shivprasad Sharma, Chaukhamba Sanskrit Series Office, Varanasi (India), 2nd edition-2008, Page No.104-05.

11. Sushrut, Sushrut-Samhita, with the NibandhaSamgraha commentary of Dalhan and Nyayachandrika Panjika of Shree Gayadas on Nidansthan edited (from beginning to $9^{\text {th }}$ chapter of Chikitsasthan) by Vaidya Yadavji Trikamji Acharya and the rest by Narayan Ram Acharya "Kavyatirth",Chaukhambha Orientalia, Varanasi (India), seventh edition- 2002, Page No.-155.

\section{References}

